\title{
Pedagogic control of schoolchildren fitness in skiing training with the help of posturography methods
}

\author{
Lazarenko M.G., Troyanovska M. M. \\ Chernigov National Pedagogical University
}

\begin{abstract}
Purpose:

Pedagogic control of schoolchildren's fitness in skiing training with the help of posturography bio-mechanical methods is regarded. To show effectiveness of posturograhy methods for determination schoolchildren' fitness in skiing training.

Material: $\quad$ in the research schoolchildren participated ( $n=90$, age 16 years). For determination schoolchildren's fitness we used the following tests: stance on left (right) foot, test for balance.

Results: $\quad$ by results of first bio-mechanical researches we determined: formed models of technique's bio-mechanical structure in skiing; registered schoolchildren's fitness; worked out methodic of schoolchildren's motor skill formation in skiing. This methodic is based on application of bio-mechanical indicators, psychological components of motor actions' control. We also found quantitative indicators of speed acceleration, pushing efforts and sliding. It permits for schoolchildren to show better result at finish.

Conclusions: for current determination of schoolchildren's fitness it is recommended to use bio-mechanical methods of posturography.

Keywords: bio-mechanical, posturography, ski training, schoolchildren, pedagogic, control.
\end{abstract}

\section{Introduction}

In Ukraine, physical education of children and youth is one of important links of preparation for integration in society [3, 4, 20, 29]). It is directed at improvement their physical and psychic health, perfection of readiness for active life, creative professional functioning $[10,12$, 22 23]. In school physical education formation of motor technique is of great importance $[8 ; 9,18,30]$.

By importance for health, physical condition and physical fitness of schoolchildren one of leading places is engaged by ski training $[7,13]$. In the process of ski training schoolchildren receive knowledge of skiing technique. They receive information about skiing hygiene, familiarize with accessories and its maintaining; they pass control tests [5]. Of not less importance is children's training to vitally significant motor skills. In such training application of posturography methods have its advantages $[1,2,32]$. Basing on individual bio-mechanical models it is possible to correct schoolchildren's and elite sportsmen's technique $[6,15]$.

Application of posturography methods permits to solve the following sport-pedagogic tasks:

- Test static-dynamic stability of sportsman's body or system of bodies; assess quantitatively and qualitatively; supplement knowledge about exercises' sport technique [11, 32];

- provide quality control of exercises' training, connected with complex motor skill of body balance [21, 28, 31, 34];

- determine the level and dynamic of motor skills' formation [17, 19, 24, 26].

Great importance is acquired by methods of schoolchildren's pedagogic control [25, 27, 33, 35]. Posturography methods were used for determination of additional qualities and skills of students in light athletics [16], choreography [14], swimming [2], volleyball (C) Lazarenko M.G., Troyanovska M. M., 2017 doi:10.15561/18189172.2017.0106
[17], outdoors games [1]. Posturography methods were also used in research of different age biathlon girls' movements in out of school establishments [15]. But we have not found study of schoolchildren's movements in skiing with the help of posturography methods.

The purpose of the research is to show effectiveness of posturography methods for determination schoolchildren' fitness in skiing training.

The tasks of the research:

1. Analysis of literature sources devoted to this topic.

2. Working out of methodic of schoolchildren's motor sills' formation in skiing with the help of bio-mechanical control methods.

3. To show effectiveness of posturography methods for determination schoolchildren' fitness in skiing training.

\section{Material and methods}

Participants: in the research schoolchildren of 16 years age participated $(n=90)$. Schoolchildren with higher results formed model group ( $M G, n=30)$. Schoolchildren with worse results formed general group (GG, $n=60$ ). GG was divided into two groups (30 persons in each): control group, which was trained by traditional methodic; experimental group (EG), which was trained by the author's methodic.

Organization of the research: the work was fulfilling during 2012-2014:

- In bio-mechanical laboratory of Chernigov National Pedagogical University, named after T.G. Shevchenko,

- In two out-of-school establishments (Chernigov specialized children-junior Olympic reserve skiing school and Chernigov regional children-junior sport school for children-orphans "Olymp”),

- In Chernigov municipal comprehensive school of $1^{\text {st }}$ $3^{\text {rd }}$ grade № 3 ,

- In Chernigov municipal information-technological 
lyceum № 16,

- Khalyavinska comprehensive school of $1^{\text {st }}-3^{\text {rd }}$ grade (Chernigov district).

For determination of schoolchildren's skills condition in skiing training we conducted stating experiment with 3 methods of posturography: "Stance on left foot", "Stance on right foot”, tests for stability. Parents gave consent for their children's participation in the research.

Statistical analysis was fulfilled with the help of Excel program.

\section{Results}

By results of correlation analysis we constructed models of oscillations of general mass center (GMC) of schoolchildren's bio-mechanical structure (see Fig.1).

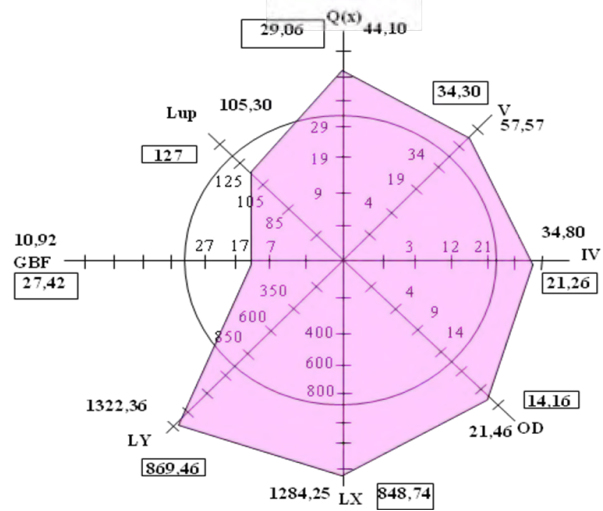

0,1 - MG $\quad 0,1$

Fig. 1. Graph-analytic model of bio-mechanical structure of test "For stability": MG - model group; GG - general group; $\mathrm{Q}(\mathrm{x})$ - dispersion by frontal axis, $\mathrm{mm}$; $\mathrm{V}$ - velocity of general mass center (GMC) traveling, $\mathrm{mm} / \mathrm{sec}$; IV - mean-amplitude value of velocity, $\mathrm{mm} / \mathrm{sec} ; \mathrm{AM}$ assessment of movement; LX - length of GMC trajectory by frontal axis, $\mathrm{mm}$; $\mathrm{LY}$ - length of GMC trajectory by sagittal axis, mm; QBF - quality of balance function, \%;
Lup - forward deviation, $\mathrm{mm}$.

In test "For stability" we see the difference by results of GG and MG indicators: GG - dispersion by frontal axis is $44.10 \pm 2.14 \mathrm{~mm}$; $\mathrm{MG}-29.06 \pm 1.46 \mathrm{~mm}$. Increase of $\mathrm{Q}(\mathrm{x})$ indicators means reduction of schoolchildren's stability in corresponding plane. Mean velocity of general mass center (GMC) traveling, is the following: GG $\mathrm{V}=57.57 \pm 5.21 \mathrm{~mm} / \mathrm{sec} ; \mathrm{MG}-\mathrm{V}=34.30 \pm 2.89 \mathrm{~mm} / \mathrm{sec}$. This indicator determines mean-amplitude value of GMC traveling velocity during testing. High velocity illustrates active processes of keeping vertical posture, connected with disorder of one or several organism's systems (for example vestibular function). The highest velocity means timely compensation of appearing body deviationsnormal work of systems, sustaining vertical posture.

Mean-amplitude value of velocity, (IV) was: GG $34.80 \pm 2.97 ; \mathrm{MG}-21.26 \pm 1.69$.

Assessment of movement (AM) was: GG 21.46 \pm 1.10 ; MG - 14.16 \pm 0.96 .

Next indicator is relation of static-kinesiograms to average dispersion, related to the time of research. Its increase says about stability worsening and decrease about improvement. The length of GMC trajectory by frontal axis (LX) was: GG - 1284.25 \pm 93.28 mm; MG $848.74 \pm 65.23 \mathrm{~mm}$.

The length of GMC trajectory by sagittal axis (LY)

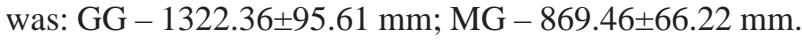

The quality of balance function (QBF) was: GG $10.92 \pm 0.85 \%$; MG $-27.42 \pm 2.11 \%$.

Forward deviation was: GG - 105.30 $\pm 6.63 \mathrm{~mm}$; MG $-127.00 \pm 4.45 \mathrm{~mm}$.

QBF indicator assesses minimal velocity of movement center (MC). The higher QBF is the better schoolchild's body stability in both planes; the better schoolchild keeps balance.

The author's methodic is built on objective bio-

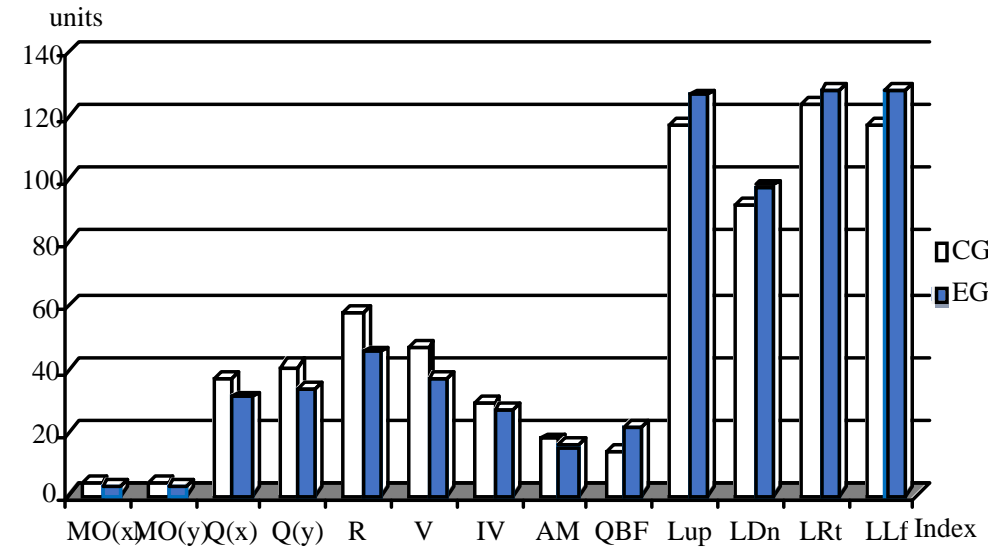

A

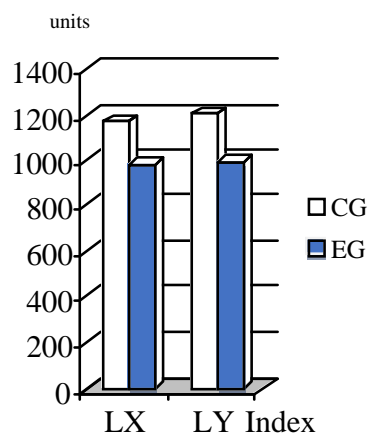

B

Fig.2. Bio-mechanical indicators of schoolchildren's static-dynamic stability (groups CG and EG) by results of test "For stability": Units - conventional units; Index - indicators; $\mathrm{MO}(\mathrm{x})$ - mean traveling by frontal axis, $\mathrm{mm}$; $\mathrm{MO}(\mathrm{y})-\mathrm{mean}$ traveling by sagittal axis, $\mathrm{mm} ; \mathrm{Q}(\mathrm{x})$-dispersion by frontal axis, $\mathrm{mm} ; \mathrm{Q}(\mathrm{y})$-dispersion by sagittal axis, $\mathrm{mm} ; \mathrm{R}$ - average dispersion, $\mathrm{mm}$; V - velocity of general mass center (GMC) traveling, $\mathrm{mm} / \mathrm{sec}$; IV - mean amplitude velocity value, $\mathrm{mm} / \mathrm{sec}$; AM - assessment of movement; QBF - quality of balance function, \%; Lup - forward deviation, $\mathrm{mm}$; LDn backward deviation, $\mathrm{mm}$; LRt - right deviation, $\mathrm{mm}$; LLf - left deviation, $\mathrm{mm}$; LX - length of GMC trajectory by frontal axis, $\mathrm{mm}$; LY - length of GMC trajectory by sagittal axis, $\mathrm{mm}$. 
Table 1. Methodic of 16 years age schoolchildren's motor skills formation in skiing training (fragment)

\begin{tabular}{|c|c|c|c|c|c|}
\hline \multirow{2}{*}{$\begin{array}{l}\text { Task } \\
1\end{array}$} & \multirow{2}{*}{$\begin{array}{l}\text { Training } \\
\text { method } \\
2\end{array}$} & \multirow{2}{*}{$\begin{array}{l}\text { Content of training } \\
3\end{array}$} & \multirow{2}{*}{$\begin{array}{l}\text { Dozing } \\
4\end{array}$} & \multicolumn{2}{|c|}{ Control indicators } \\
\hline & & & & 5 & 6 \\
\hline \multirow{6}{*}{$\begin{array}{l}\text { 1. To form the feel- } \\
\text { ing of skis cohesion } \\
\text { with snow }\end{array}$} & \multicolumn{3}{|l|}{ Training 1} & $\mathrm{Q}(\mathrm{x}) \mathrm{mm}$ & $3.37 \pm 0.18$ \\
\hline & \multirow{2}{*}{\multicolumn{3}{|c|}{ Control of static-dynamic stability indicators in schoolchildren }} & $\mathrm{Vmm}$ & $30.02 \pm 1.49$ \\
\hline & & & & $\mathrm{R} \mathrm{mm}$ & $4.19 \pm 0.21$ \\
\hline & \multicolumn{5}{|c|}{ In gym: (preparatory part) } \\
\hline & & 1.Theory. & 5 minutes & \multirow{3}{*}{$\begin{array}{l}60 \text { m run, } \\
\text { sec. }\end{array}$} & \\
\hline & Explanations & 2. Warming up. General (GE). & 3 minutes & & $10.20 \pm 0.67$ \\
\hline \multirow{2}{*}{$\begin{array}{l}\text { 2. To master coor- } \\
\text { dination of arms, } \\
\text { torso, legs move- } \\
\text { ments; balance }\end{array}$} & \multirow{2}{*}{$\begin{array}{l}\text { Demonstra- } \\
\text { tions } \\
\text { Practical }\end{array}$} & $\begin{array}{l}\text { 3. Special power exercises (SPE) on } \\
\text { simulator "Belts with rings". }\end{array}$ & 3 minutes & & $8.2 \pm 0.74$ \\
\hline & & $\begin{array}{l}\text { 4. Exercises for mastering forms of } \\
\text { arms, torso and legs movements } \\
\text { (imitation of skiing). }\end{array}$ & 1 minute. & $\begin{array}{l}\text { Shuttle run } \\
4 \times 9 \mathrm{~m} \\
\text { sec. }\end{array}$ & $9.20 \pm 1.05$ \\
\hline \multirow{3}{*}{$\begin{array}{l}\text { 3. To master move- } \\
\text { ments of legs, arms } \\
\text { and torso in ski } \\
\text { stepping and sliding }\end{array}$} & \multicolumn{3}{|c|}{ On snow (main part) } & \multirow{3}{*}{$\begin{array}{l}3 \text { km run, } \\
\text { minutes }\end{array}$} & \\
\hline & Explanations & Jumping on skis on the spot: & & & \\
\hline & $\begin{array}{l}\text { Demonstra- } \\
\text { tions } \\
\text { Practical }\end{array}$ & $\begin{array}{l}\text { 1. Alternating legs with the help and } \\
\text { without ski sticks with GMC transfer. } \\
\text { 2. On both skis with and without } \\
\text { help of sticks, with turning skis to } \\
\text { the right and to the left. }\end{array}$ & $\begin{array}{l}30 \text { seconds for } \\
\text { every exercise }\end{array}$ & & \\
\hline \multirow{8}{*}{$\begin{array}{l}\text { 4. Mastering of } \\
\text { motor skills: endur- } \\
\text { ance, flexibility, } \\
\text { dexterity, quickness } \\
\text { and strength. }\end{array}$} & $\begin{array}{l}\text { Leading up } \\
\text { exercises: }\end{array}$ & $\begin{array}{l}\text { 3. On one right or left ski with and } \\
\text { without sticks with turning skis to } \\
\text { the left or to the right. }\end{array}$ & & \multirow{8}{*}{$\begin{array}{l}\text { Skiing by } \\
\text { skate style, } \\
5 \mathrm{~km} \text {, min- } \\
\text { utes. } \\
\text { Skiing by } \\
\text { classic style, } \\
3 \mathrm{~km} \text {, min- } \\
\text { utes. } \\
\text { Chin ups, } \\
\text { quantity of } \\
\text { times. } \\
\text { Long jump } \\
\text { from the } \\
\text { spot, m. }\end{array}$} & $14.20 \pm 1.11$ \\
\hline & Demonstra- & $\begin{array}{l}\text { Demonstration of ski stepping with } \\
\text { and without sticks }\end{array}$ & $\begin{array}{l}\text { Training circle - } \\
200 \text { meters }\end{array}$ & & $9.10 \pm 0.66$ \\
\hline & & $\begin{array}{l}\text { 1. Slow ski stepping and sliding with } \\
\text { and without sticks }\end{array}$ & One circle for & & \\
\hline & Uniform & $\begin{array}{l}\text { 2. Slow sliding on one ski with and } \\
\text { without sticks. }\end{array}$ & $\begin{array}{l}\text { every exercise } \\
\text { individually. }\end{array}$ & & $22.8 \pm 1.33$ \\
\hline & $\begin{array}{l}\text { Uniform } \\
\text { In gym (finaliz }\end{array}$ & $\begin{array}{l}\text { 3. Skiing with alternative classic } \\
\text { style with sticks and without them. } \\
\text { ng part) }\end{array}$ & 60 minutes. & & $2.70 \pm 0.21$ \\
\hline & \multirow{3}{*}{$\begin{array}{l}\text { Circular } \\
\text { Encourage- } \\
\text { ment }\end{array}$} & $\begin{array}{l}\text { 1. Chin ups, rising of legs, pressing } \\
\text { ups on simulator "Parallel bars- } \\
\text { horizontal bar". }\end{array}$ & $\begin{array}{l}3 \text { times with } \\
100 \% \text { efforts }\end{array}$ & & \\
\hline & & 2. Squatting on one leg & $\begin{array}{l}3 \text { times for } \\
\text { every leg with } \\
100 \% \text { efforts }\end{array}$ & & \\
\hline & & $\begin{array}{l}\text { 3. Special power exercises (SPE) on } \\
\text { simulator "Belts with rings". }\end{array}$ & 5 minutes. & & \\
\hline
\end{tabular}

mechanical analysis and modeling. The methodic has exact tasks with preparatory and special power exercises, required trainings methods, load dozing, biomechanical control indicators in the basis (see table 1).

In one year after the author's methodic application we determined effectiveness of the offered methodic, resulted from formation experiment by the same 3 methods of posturography (see Fig.2).

It was proved that in EG, comparing with CG schoolchildren there were confident changes and results improved in tests "Stance on left foot" - by $20.54 \%$; "Stance on right foot - by $18.18 \%$. It proves effectiveness of posturography methods in determination of schoolchildren's skills in ski training.

\section{Discussion}

Analysis of scientific-methodic literature and own practical experience shows that the problem of development and implementation bio-mechanical control methods in pedagogic process (meaning control over schoolchildren's skills formation at ski training) has been still insufficiently studied.

Students' motor fitness was determined with the help of biomechanical control methods in light athletics, choreography, swimming, volleyball, outdoors games $[1,2,14,17]$. In biathlon motor fitness of schoolgirls was determined [15]. In all cases the methods of biomechanical control were applied. All results proved effectiveness of bio-mechanical methods.

On the base of the received by us data we constructed bio-dynamic parameters' models of schoolchildren's supporting reactions in skiing. Besides, we found difference between control, experimental and model groups. 
The author's methodic of schoolchildren skills' formation in ski training process is an integrated system of motor skills formation. It is based on application of bio-mechanical indicators and psychological components of motor control. Earlier we conducted theoretical studies with the help of posturography tests $[5,6,15]$, in the base of which calculated data were. In the present work we received actual characteristics of posturography parameters, which were used in ski training. Such approach to formation of motor skills significantly increases skiing technique. The methodic considers psycho-emotional state of schoolchild. Pedagogue helps schoolchild to choose optimal skiing speed, considering quantitative indicators of acceleration, pushes and sliding. It permits for the schoolchild to achieve higher results at finish.

\section{Conclusions}

For the first time methodic of schoolchildren's skiing motor skills has been worked out and implemented in practice.

Effectiveness of posturography methods in determination of schoolchildren's fitness in ski training has been proved.

For determination of fitness level it is necessary to select bio-mechanical control methods, according to age.

\section{Acknowledgements}

The study was fulfilled in compliance with combine plan of scientific-research works of Chernigov National Pedagogical University, named after T.G. Shevchenko: "Didactic principles of motor function's formation in persons, practicing physical education and sports" (№ 0108U000854 , dt. February 19, 2008).

\section{Conflict of interests}

The author declares that there is no conflict of interests.

\section{References:}

1. Bojko OO. Rozvitok rukhovikh navichok u majbutnikh uchiteliv fizichnoi kul'turi na zaniattiakh zi sportivnikh igor. Kand. Diss. [Training of future physical culture teachers' motor skills at outdoors games classes. Cand. Diss.], Chernihiv; 2012. (in Ukrainian)

2. Dejneka SM. Metodika formuvannia rukhovikh umin' $i$ navichok majbutnikh uchiteliv fizichnogo vikhovannia $v$ procesi fakhovoi pidgotovki. Kand. Diss. [Methodic of future physical culture teachers' motor skills' formation in the process o vocational training. Cand. Diss.], Chernihiv; 2012. (in Ukrainian)

3. Iermakov SS. Modeli biomekhanicheskikh sistem v organizacii effektivnogo dejstviia sportsmena [Models of biomechanical systems in organization of sportsman's effective functioning]. Pedagogics, psychology, medical-biological problems of physical training and sports, 2001;17:40-47. (in Russian)

4. Iermakov SS. Pedagogicheskie podkhody $\mathrm{v}$ obuchenii slozhnym tekhnicheskim priemam iunykh volejbolistov [Psychological approaches to training junior volleyball players to complex techniques]. Pedagogics, psychology, medical-biological problems of physical training and sports, 2001;2:32-42. (in Russian)

5. Lazarenko MG. Pedagogichni aspekti rukhovikh umin' i navichok starshoklasnikiv pid chas zmagan' $\mathrm{z}$ biatlonu [Pedagogic aspects of senior school pupils' motor skills in biathlon competitions]. Naukovo-pedagogichni problemi fizichnoi kul 'turi, 2013;7(33):441-445. (in Ukrainian)

6. Lazarenko NG. Teoretiko-pedagogicheskij analiz vliianiia urovnia sformirovannosti dvigatel'nykh umenij i navykov starsheklassnikov na rezul'tat v lyzhnykh gonkakh [Theoretical-pedagogic analysis of influence of senior school pupils motor skills' level result in ski racings]. Fizicheskaia kul'tura, sport i turizm, 2014;11(2):95-101. (in Russian)

7. Lazarenko MG. Pedagogical aspects of effective use of simulator "Straps with ring" during the formation motor skills of pupils of 10 classes during the skiing training in the lessons of physical culture. Physical education of students, 2014;6:24-28. doi:10.15561/20755279.2014.0605

8. Laputin AN, Khapko VE. Biomekhanika fizicheskikh uprazhnenij [Bio-mechanic of physical exercises], Kiev:
High School; 1989. (in Russian)

9. Litovchenko GO, Kozeruk IuV, Lazarenko MG, Troianovs'ka MM. Osnovi fizichnogo vikhovannia liudej riznogo viku [Principles of physical education of different age people], Chernihiv: CHNPU; 2012. (in Ukrainian)

10.Nosko MO. Teoretichni ta metodichni osnovi formuvannia rukhovoi funkcii u molodi pid chas zaniat' fizichnoiu kul'turoiu ta sportom. Dokt. Diss. [Theoretical and methodic principles of motor function's formation in youth, practicing physical culture and sports. Doct. Diss.], Kiev; 2003. (in Ukrainian)

11.Nosko MO. Navchannia fizichnim vpravam [Training of physical exercises]. Pedagogics, psychology, medicalbiological problems of physical training and sports, 2001;17:7-9. (in Ukrainian)

12.Nosko NA. Pedagogicheskie osnovy obucheniia molodezhi i vzroslykh dvizheniiam so slozhnoj biomekhanicheskoj strukturoj [Pedagogical principles of youth's and adults' training to movements with complex bio-mechanical structure]. Kiev: Scientific World; 2000. (in Russian)

13.Nosko MO, Lazarenko MG, Dejkun MP. Teoretichnij analiz biomekhanichnikh osnov rukhovikh umin' i navichok starshoklasnikiv u procesi lizhnoi pidgotovki [Theoretical analysis of senior school pupils' motor skills' bio-mechanical principles in the process of ski training]. Visnik Chernigivs'kogo nacional'nogo pedagogichnogo universitetu, 2013;112:173-176. (in Ukrainian)

14.Solonec' Iulu. Rozvitok rukhovoi koordinacii majbutnikh uchiteliv fizichnoi kul'turi u procesi zaniat' z khoreografii. Kand. Diss. [Training of future physical culture teachers' motor coordination in the process of choreography classes. Cand. Diss.], Chernihiv; 2012. (in Ukrainian)

15.Troyanovska MN. Determining the level of a high school student qualities of coordination in the process by biathlon training stabilography. Pedagogics, psychology, medicalbiological problems of physical training and sports, 2015;2:70-74. doi:10.15561/18189172.2015.0212

16.Filipov VV. Rozvitok koordinacijnikh zdibnostej majbutnikh uchiteliv fizichnoi kul 'turi v procesi zaniat' legkoiu atletikoiu. Kand. Diss. [Training of future physical culture teachers' coordination in the process of light athletics classes. Cand. Diss.], Chernihiv; 2010. (in Ukrainian)

17.Filonenko OA. Formuvannia rukhovikh navichok 
starshoklasnic' u procesi zaniat' volejbolom na urokakh fizichnoi kul'turi. Kand. Diss. [Formation of senior schoolgirls' motor skills at volleyball trainings at physical culture lessons. Cand. Diss.], Chernihiv; 2011. (in Ukrainian)

18. Bliznevsky AA, Kudryavtsev MD, Iermakov SS, Jagiello W. Formation of active-effective attitude of 12-13 years' judo athletes to sports functioning in competition period. Archives of Budo, 2016;12:101-115.

19.Bodnar IR, Andres AS. Tests and standards for expresscontrol of physical fitness and health of middle school age pupils. Pedagogics, psychology, medical-biological problems of physical training and sports, 2016;4:11-16. doi:10.15561/18189172.2016.0402

20.Bodnar IR, Stefanyshyn MV, Petryshyn YV. Assessment of senior pupils' physical fitness considering physical condition indicators. Pedagogics, psychology, medical-biological problems of physical training and sports, 2016;6:9-17. doi:10.15561/18189172.2016.0602

21.Boloban VN, Tereshchenko IA, Otsupok AP, Krupenia SV, Kovalenko YO, Otsupok AnP. Perfection of coordination with the help of jump exercises on trampoline. Physical Education of Students, 2016;6:4-17. doi:10.15561/20755279.2016.0601

22.Gaskov AV, Kuzmin AV, Kudryavtsev DM, Iermakov SS. Successfulness of general and special physical qualities' development on different stage of students-boxers' training. Physical Education of Students, 2016;1:4-11. doi:10.15561/20755279.2016.0101

23.Iermakov SS, Arziutov GN, Jagiełło W. Quick training of students to judo techniques. Archives of Budo, 2016;12:1524.

24.Ivashchenko O, Khudolii O, Yermakova T, Iermakov S, Nosko M, Nosko Y. Factorial and discriminant analysis as methodological basis of pedagogic control over motor and functional fitness of 14-16 year old girls. Journal of Physical Education and Sport, 2016;16(2):442-451. doi:10.7752/ jpes.2016.02068

25.Ivashchenko OV. Methodic of pedagogic control of 1617 years' age girls' motor fitness. Pedagogics, psychology, medical-biological problems of physical training and sports, 2016;5:26-32. doi:10.15561/18189172.2016.0504

26.Ivashchenko OV, Kapkan OO. Informative pedagogic control indicators of 14-15 years age girls' motor fitness. Pedagogics, psychology, medical-biological problems of physical training and sports, 2016;6:18-25. doi:10.15561/18189172.2016.0603

27.Khudolii OM, Iermakov SS, Prusik K. Classification of motor fitness of 7-9 years old boys. Journal of Physical Education and Sport, 2015;15(2):245-253. doi:10.7752/ jpes.2015.02038

28.Kovalenko YO, Boloban VN. Structural elements of construction of individual and group exercises' competition compositions in calisthenics. Physical Education of Students, 2016;1:12-20. doi:10.15561/20755279.2016.0102

29.Kozina ZL, Iermakov SS, Kadutskaya LA, Sobyanin FI, Krzeminski M, Sobko IN, Ryepko OA. Comparative characteristic of correlation between pulse subjective indicators of girl students' and school girls' reaction to physical load. Physical Education of Students, 2016;4:24-34. doi:10.15561/20755279.2016.0403

30.Malinauskas R. The dynamics of values among future sport pedagogues in the last decade. [Būsimujjų sporto pedagogų vertybių dinamika pastaraji dešimtmeti] Pedagogika, 2016;121(1):70-82. doi:10.15823/p.2016.05

31.Malinauskas R, Dumciene A, Mamkus G, Venckunas T. Personality traits and exercise capacity in male athletes and non-athletes. Perceptual and Motor Skills, 2014;118(1):145161. doi:10.2466/29.25.PMS.118k13w1

32.Nosko M, Razumeyko N, Iermakov S, Yermakova T. Correction of 6 to 10-year-old schoolchildren postures using muscular-tonic imbalance indicators. Journal of Physical Education and Sport, 2016;16(3):988-999. doi:10.7752/ jpes.2016.03156

33.Podrigalo LV, Iermakov SS, Alekseev AF, Rovnaya OA. Studying of interconnections of morphological functional indicators of students, who practice martial arts. Physical Education of Students, 2016;1:64-70. doi:10.15561/20755279.2016.0109

34.Radziminska A., Weber-Rajek M., Lulinska-Kuklik E, Kazmierczak U, Moska W. Academic youth's health behavior. Physical Education of Students, 2016;6:55-62. doi:10.15561/20755279.2016.0607

35.Sniras S, Malinauskas R. Moral skills of schoolchildren. Social Behavior and Personality, 2005;33(4):383-390.

\section{Information about the authors:}

Lazarenko M.G.; http://orcid.org/0000-0003-3308-5154; lazarenko.nikolay@gmail.com; Chernigov National Pedagogical University; Getman Polubotka str. 53, Chernigov, 14013, Ukraine.

Troyanovska M.N.; http://orcid.org/0000-0002-7676-8468; masha.lazarenko@bigmir.net; Chernigov National Pedagogical University ; Getman Polubotka str. 53, Chernigov, 14013, Ukraine.

Cite this article as: Lazarenko MG, Troyanovska MM. Pedagogic control of schoolchildren fitness in skiing training with the help of posturography methods. Pedagogics, psychology, medical-biological problems of physical training and sports, 2017;1:36-40. doi:10.15561/18189172.2017.0106

The electronic version of this article is the complete one and can be found online at: http://www.sportpedagogy.org.ua/index.php/PPS/issue/archive

This is an Open Access article distributed under the terms of the Creative Commons Attribution License, which permits unrestricted use, distribution, and reproduction in any medium, provided the original work is properly cited (http://creativecommons.org/licenses/by/4.0/deed.en).

Received: 06.12.2016

Accepted: 05.01.2017; Published: 24.01.2017 